\title{
Comparison of DNA quality in raw and reconstituted milk during sterilization
}

\author{
J. Liao, ${ }^{*}$ L. Yang, ${ }^{*}$ A. M. Sheppard, $†$ and Y. F. Liu ${ }^{* 1}$ \\ ${ }^{*}$ College of Food Engineering and Nutritional Science, Shaanxi Normal University, Xi'an 710062, China \\ †Liggins Institute, The University of Auckland, Auckland 1023, New Zealand
}

\section{ABSTRACT}

Responses to milk sterilization are usually evaluated only in terms of physicochemical properties and microbial safety, thus undervaluing the importance of DNA quality in an authentication process by methods based on PCR. Because DNA is a heat-sensitive molecule, we hypothesized that the heating process may impair the detection or quantification of DNA in raw fresh milk (FM) or reconstituted milk (RM), and that differences in DNA quality might exist between FM and RM. We thus investigated the effects of sterilization on the quality of DNA extracted from FM or RM; differences in DNA quality between FM and RM were also evaluated. The quality of extracted DNA from FM or RM was assessed by the specific detection of FM or RM composition in goat milk mixtures using primers targeting the bovine $12 S$ gene, as well as by monitoring DNA yield, purity, ratio of mitochondrial (mt) to nuclear (n) DNA, and the level of DNA degradation. Polymerase chain reaction readily detected both untreated and heat-treated FM or RM in cow-goat milk mixtures, and gave a good sensitivity threshold $(0.1 \%)$ under all sterilization conditions. The DNA yield and mtDNA: nDNA ratio of FM and RM varied significantly during the sterilization process. These results demonstrated that the sterilization altered the quantification of DNA in FM or RM during sterilization, but DNA could still be readily detected in sterilized FM or RM by PCR. Furthermore, we noted significant differences in DNA integrity, yield, and mtDNA:nDNA ratio between FM and RM during sterilization, which may have potential as a means to distinguish FM and RM.

Key words: milk, sterilization, DNA quality, PCR

\section{INTRODUCTION}

It has been widely recognized that mislabeling of food products and ingredient substitutions are major

\footnotetext{
Received July 8, 2017.

Accepted September 14, 2017.

${ }^{1}$ Corresponding author: yongfeng200@126.com
}

issues in nutritional quality and food safety (Wong and Hanner, 2008; Cawthorn et al., 2013; Everstine et al., 2013). With the increase in global trade of food products, accurate and speedy authentication is essential for correct labeling to ensure food safety. The use of PCR authentication has become one of the prospective standards recently. Such PCR-based monitoring approaches are limited, however, by the relatively low content and extractability of DNA of adequate quality, both of which depend upon the initial sample's purity and subsequent degree of DNA degradation (Spaniolas et al., 2008).

Nevertheless, manufacturing of food products usually involves heat treatment, and DNA quality is often deteriorated by food processing, result in the degradation of DNA into small fragments (Novak et al., 2007). For example, Chen et al. (2005) reported that the size of DNA in a soybean product was reduced after sterilization. Studies on meat processing revealed that the DNA fragment size was progressively degraded into smaller fragments with increasing duration of heating and temperature (Guoli et al., 1999; Sakalar et al., 2012; Musto et al., 2014).

In terms of dairy products, to ensure total microbiological safety and extend shelf life of milk, sterilization is most often achieved through UHT processing, from about 135 to $145^{\circ} \mathrm{C}$ for just a few seconds, or by retort processing, in which liquid milk is heated only to a temperature of about 110 to $120^{\circ} \mathrm{C}$ but for several minutes. In this context, sterilization can become the crucial aspect in an authentication process by PCRbased methods. At present, studies about the effects of heating process on DNA quality in milk are mainly focused on sensitivity analysis (López-Calleja et al., 2004, 2005; Liao et al., 2017b); the degradation of DNA in milk during sterilization has not been evaluated.

Until recently, sterilized milk products were produced from raw fresh (FM); however, the number of commercially available sterilized milk products derived from reconstituted milk ( $R \mathbf{M})$ has increased in recent years. Therefore, monitoring the changes of DNA quality in FM and RM during sterilization is an important initial step for optimizing any DNA-based analytical 
protocols. Considering the results obtained from previous studies (López-Calleja et al., 2004, 2005; Liao et al., $2017 \mathrm{~b}$ ) and the lack of reports on DNA quality from sterilized FM and RM, the primary aim of the current study was to investigate the effects of sterilization on the quality of DNA extracted from FM and RM; we also evaluated differences in DNA quality between FM and RM.

\section{MATERIALS AND METHODS}

\section{Sample Collection and Experiment Design}

Authentic samples of pooled FM from cow were obtained from the collection tank of local dairy farm. Samples were transported on ice packs (to maintain an optimum low temperature) to the laboratory and processed immediately or stored at $-80^{\circ} \mathrm{C}$ until used. Milk powder was produced by using the FM described above, according to the method of Martin et al. (2008). Then, the powder was reconstituted in distilled water to yield RM of the same overall composition as the source FM. A total of $30 \mathrm{FM}$ and $30 \mathrm{RM}$ samples were prepared and sterilized by autoclaving according to a previous study with some modifications (Corredig and Dalgleish, 1996). Briefly, each milk sample was transferred into 50-mL capped glass centrifuge tubes and sterilized at $121^{\circ} \mathrm{C}$ for 0 (raw control), 1, 5, 10 and 15 min, respectively (Table 1 ).

Six FM and 6 RM samples from each treatment were used for DNA extraction and quality evaluation; each sample was tested in duplicate. In addition, to determine whether the DNA from different processed FM and RM gave rise to comparable sensitivity in adulteration detection, various proportions $(0.1,0.5,1,10$, and $30 \%$ ) of FM or RM in goat milk were prepared for DNA extraction and further PCR analysis; each sample was also tested in duplicate. The goat milk samples were also sourced from the collection tank of local dairy farm and their species was authenticated.

\section{DNA Extraction and Quality Evaluation}

DNA Extraction. The DNA was extracted from milk according to our previous work (Liu et al., 2014), with slight changes. Briefly, $10 \mathrm{~mL}$ of milk was centrifuged for $10 \mathrm{~min}$ at $4,150 \times \mathrm{g}$. The top and middle layers were removed, leaving the bottom sediment, which was washed twice with $600 \mu \mathrm{L}$ of PBS (pH 7.4, $4.8 \mu \mathrm{g}$ of $\mathrm{NaCl}, 0.12 \mu \mathrm{g}$ of $\mathrm{KCl}, 0.864 \mu \mathrm{g}$ of $\mathrm{Na}_{2} \mathrm{HPO}_{4}$, $0.144 \mu \mathrm{g}$ of $\mathrm{KH}_{2} \mathrm{PO}_{4}$, and $600 \mu \mathrm{L}$ of double distilled $\left.\mathrm{H}_{2} \mathrm{O}\right)$. After the washing step, the sediment was mixed with $350 \mu \mathrm{L}$ of extraction buffer $(\mathrm{pH} 8.0,100 \mathrm{mM}$ Tris
$\mathrm{Cl}, 100 \mathrm{~m} M \mathrm{NaCl}$, and $5 \mathrm{~m} M \mathrm{EDTA}), 50 \mu \mathrm{L}$ of $20 \%$ (wt/vol) SDS, and $10 \mu \mathrm{L}$ of proteinase $\mathrm{K}(20 \mathrm{mg} / \mathrm{mL}$ ), and incubated at $56^{\circ} \mathrm{C}$ for $4 \mathrm{~h}$. The mixture was extracted with an equal volume of Tris-phenol, phenol: chloroform:isoamyl alcohol (volume ratio of 25:24:1), and chloroform:isoamyl alcohol (volume ratio of 24:1). Finally, DNA was precipitated with ice-cold absolute ethanol and washed once with ethanol:water (volume ratio of 7:3). Twenty-five microliters of Tris-EDTA ( $\mathrm{pH}$ $=8.0,1 \mathrm{~m} M$ Tris- $\mathrm{Cl}$ and $0.5 \mathrm{~m} M$ EDTA) was added to dissolve DNA.

DNA Yield, Purity, and Integrity. The DNA yield (expressed as $\mathrm{ng} / \mathrm{mL}$ of milk) was calculated using a UV/visible spectrophotometer (Thermo Fisher Scientific Inc., Waltham, MA) and the absorbance (A) ratio at 260 and $280 \mathrm{~nm}\left(\mathrm{~A}_{260} / \mathrm{A}_{280}\right)$ was taken as a purity index. The level of degradation of extracted DNA was examined by agarose gel electrophoresis, visualized using UV light, and digitally photographed.

PCR Amplification. The cow-specific primer 12SBT-REV was selected for specific detection of FM or $\mathrm{RM}$ compositions in goat milk mixtures by amplifying a 346-bp fragment in the $12 S$ gene. The sequence of the primer was adopted from López-Calleja et al. (2005): 5'-CTAGAGGAGCCTGTTCTATAATCGATAA-3' and $5^{\prime}$-AAATAGGGTTAGATGCACTGAATCCAT- $3{ }^{\prime}$. The PCR reaction consisted of $3.4 \mu \mathrm{L}$ of $2 \times$ TaqMan Universal PCR Master Mix (CWBIO, Beijing, China), $0.3 \mu \mathrm{L}$ of assay-specific forward and reverse primers, $1 \mu \mathrm{L}$ of the template DNA, in a total volume of 10 $\mu \mathrm{L}$ with DNase-/DNA-free water (CWBIO). The PCR protocol was $95^{\circ} \mathrm{C}$ for $10 \mathrm{~min}$ followed by 30 cycles of $94^{\circ} \mathrm{C}$ for $30 \mathrm{~s}, 63^{\circ} \mathrm{C}$ annealing for $30 \mathrm{~s}$, and $72^{\circ} \mathrm{C}$ for $30 \mathrm{~s}$, and a final extension at $72^{\circ} \mathrm{C}$ for 10 min using an Aritik PCR System (Thermo Fisher Scientific Inc., Waltham, MA). The amplification products were resolved by electrophoresis agarose gel and visualized under UV light and digitally photographed.

Real-Time PCR Amplification. To determine the relative quantity of mitochondrial (mt)DNA products, $12 S$, a gene specific in the mitochondrial genome, and bovine $H B B$, a housekeeping gene acting as the nuclear

Table 1. Sterilization times and endpoint core temperatures (mean \pm $\mathrm{SD})$ of autoclaving sterilization

\begin{tabular}{lc}
\hline $\begin{array}{l}\text { Sterilization time } \\
(\mathrm{min})\end{array}$ & $\begin{array}{c}\text { Endpoint core } \\
\text { temperature }\left({ }^{\circ} \mathrm{C}\right)\end{array}$ \\
\hline 0 & Raw control \\
1 & $66.23 \pm 0.25$ \\
5 & $76.00 \pm 0.50$ \\
10 & $84.70 \pm 0.35$ \\
15 & $94.23 \pm 0.25$ \\
\hline
\end{tabular}


(n) control gene (nDNA), were used. The primer $12 S$ was adopted from Laubenthal et al. (2016): 5'-CGCGGTCATACGATTAACCC-3' and 5'-AACCCTATTTGGTATGGTGCTT- $3^{\prime}$. The primer for $H B B$ was adopted from Brown et al. (2012): 5'-CGGCGGCGGGCGGCGCGGGCTGGGCGGGAAGGCCCATGGCAAGAAGG-3' and 5'-GCCGGCCCGCCGCGCCCGTCCCGCCGCTCACTCAGCGCAGCAAAGG-3'. A single qPCR was set up by adding $5 \mu \mathrm{L}$ of SYBR Green mixture (CWBIO), $0.4 \mu \mathrm{L}$ of $12 S(H B B)$ forward and reverse primers, $1 \mu \mathrm{L}$ of template DNA, and $3.2 \mu \mathrm{L}$ of nuclease-free water in a final volume of $10 \mu \mathrm{L}$. The PCR conditions were $95^{\circ} \mathrm{C}$ for $10 \mathrm{~min}$ followed by 40 cycles of $94^{\circ} \mathrm{C}$ for $30 \mathrm{~s}, 60^{\circ} \mathrm{C}$ annealing for $60 \mathrm{~s}$, and $72^{\circ} \mathrm{C}$ for $60 \mathrm{~s}$, and a final extension at $72^{\circ} \mathrm{C}$ for $10 \mathrm{~min}$ using a Piko Real 96 real-time PCR System (Thermo Fisher Scientific). The relative quantity of mtDNA products was calculated according to the following equation (Nicklas et al., 2004): mtDNA:nDNA = $2^{-(\mathrm{Ct} 12 S-\mathrm{Ct} H B B)}$, where $\mathrm{Ct}=$ cycle threshold.

\section{Statistical Analysis}

Results were analyzed by ANOVA, and Duncan's multiple range tests were used to assess differences between means with 95\% significance level using SPSS version 21.0 (SPSS Inc., Chicago, IL).

\section{RESULTS}

\section{DNA Yield, Purity, and Integrity}

The results of DNA yield and purity are reported in Table 2. Compared with untreated FM, heat-treated FM showed a significant increase in DNA yield $(P<$ $0.05)$. For RM, the DNA yield varied during sterilization $(P<0.05)$. When comparing DNA yields between
FM and RM, the yield from RM under all heat treatments was higher than that from FM $(P<0.05)$.

The purity of DNA from FM ranged from 1.49 to 1.56 and we did not find any significant differences between heat-treated and untreated FM. However, the purity of DNA from heat-treated RM was lower than that from untreated RM $(P<0.05)$. When comparing the purity between FM and RM, we observed that purity of DNA from heat-treated RM was lower than that from heattreated FM $(P<0.05)$.

To determine whether sterilization would result in DNA degradation in FM and RM, we examined DNA extracted from FM and RM by direct agarose gel electrophoresis. We found that bands from FM was heated for $1 \mathrm{~min}$ were fainter and eventually disappeared in FM heated for up to 15 min (Figure 1A). The bands obtained were also fainter in RM heated for $1 \mathrm{~min}$, and intact bands were degraded to about $250 \mathrm{bp}$ in RM heated for up to 5 and $10 \mathrm{~min}$, and eventually disappeared in RM heated for up to 15 min (Figure 1B). When comparing the bands between FM and RM, the bands in FM were clear and consistent, with good integrity and no smearing or diffusion. In contrast, the bands in RM were more degraded and less intact.

\section{PCR Amplification}

To determine the effects of sterilization on the detection limit of PCR, amplification reactions were performed using DNA extracted from binary milk mixtures of cow milk in goat at $0.1,0.5,1,10$, and $30 \%$ (vol/ vol) of different heat-processed FM or RM. The PCR results were specific and sensitive, and all untreated and heat-treated FM and RM samples showed the same detection threshold $(0.1 \%)$ in cow-goat milk mixtures (Figure 2).

Table 2. Evaluation of DNA yield, purity, and the ratio of mitochondrial to nuclear DNA (mtDNA:nDNA) from fresh (raw) milk (FM) and reconstituted milk (RM) after different sterilization times ${ }^{1}$

Sterilization time $(\mathrm{min})$

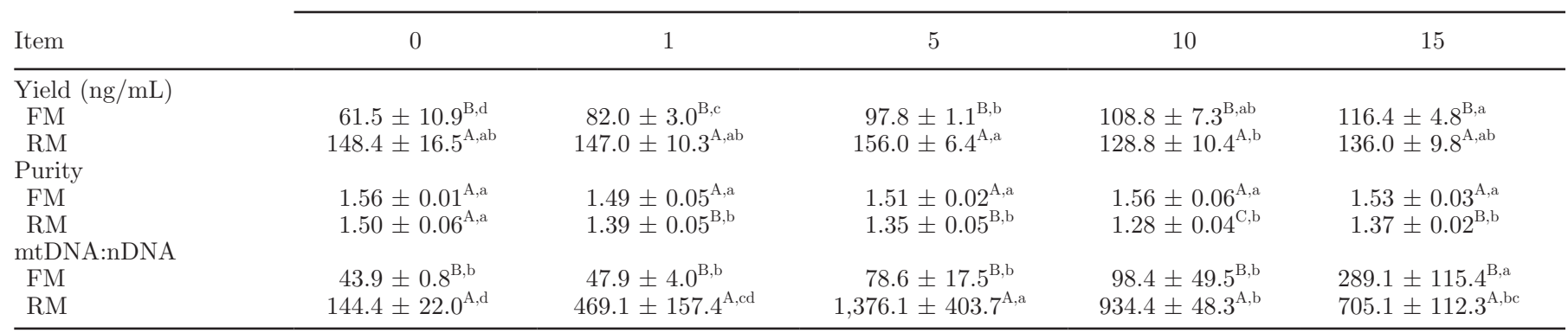

${ }^{\mathrm{A}-\mathrm{C}}$ Means in a column with different uppercase letters within a variable are significantly different $(P<0.05)$.

${ }^{\mathrm{a}-\mathrm{d}}$ Means in a row with different lowercase letters within a variable are significantly different $(P<0.05)$.

${ }^{1}$ Values are means \pm SD. 

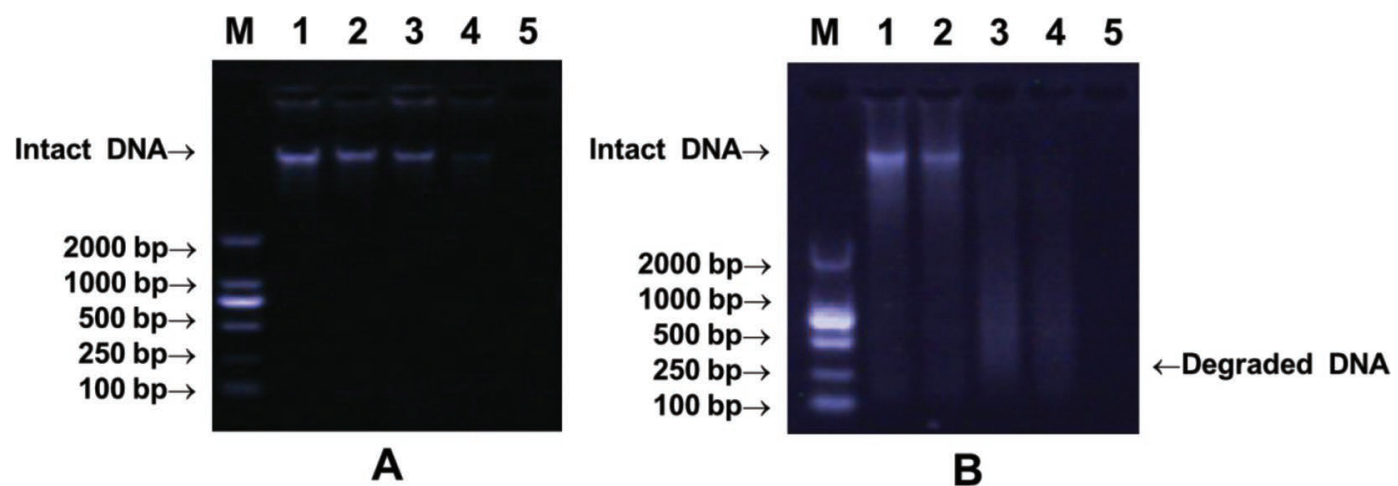

Figure 1. Representative gel electrophoresis of DNA extracted from fresh milk (FM; A) and reconstituted milk (RM; B), which were subject to sterilization for 0 (lane 1), 1 (lane 2), 5 (lane 3), 10 (lane 4), and 15 (lane 5) min; M = molecular weight marker (2,000-bp DNA ladder). Color version available online.

\section{Real-Time PCR Amplification}

The Ct values of $12 S$ and $H B B$ in untreated and heat-treated FM and RM are shown in Figure 3. The Ct values of $12 S$ in heat-treated FM and RM did not differ statistically from untreated FM and RM $(P>$ 0.05), suggesting that amplification of mtDNA was stable after sterilization of FM and RM. Compared with untreated samples, the $\mathrm{Ct}$ values of $H B B$ were significantly higher when FM and RM were heated for up to $10 \mathrm{~min}$ and $1 \mathrm{~min}$, respectively. These results suggest that the nDNA in both FM and RM can be damaged by sterilization.

The ratios of mtDNA:nDNA from FM and RM are reported in Table 2. The mtDNA:nDNA ratios in both FM and RM increased after sterilization $(P<0.05)$. In addition, the mtDNA:nDNA ratio from RM was higher than that from FM under all sterilization conditions $(P$ $<0.05)$.

\section{DISCUSSION}

Because DNA is a heat-sensitive molecule, it is subject to varying degrees of damage during food processing (Bauer et al., 2003; Bergerová et al., 2011; Song et al., 2011; Ballari and Martin, 2013). In particular, the production of milk products most often requires heat treatment to ensure safety and extend shelf life. The DNA present in final milk products is thus likely to be compromised after standard sterilization procedures that are used commercially. A large number of food products are subjected to chemical, physical, and biological processing. Autoclave treatment is often used as one of the processing models in food analysis studies (Yoshimura et al., 2005). We thus investigated the effects of autoclaving on the quality of DNA present in FM and RM. As the demand for milk products by consumers has increased, both FM and RM represent important base materials in the production of sterilized

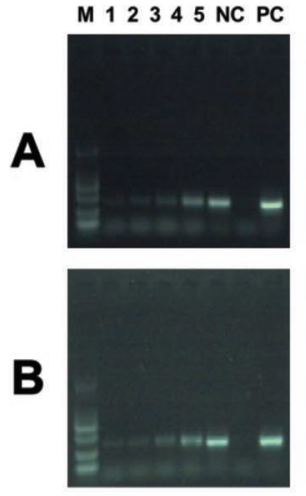

0 min
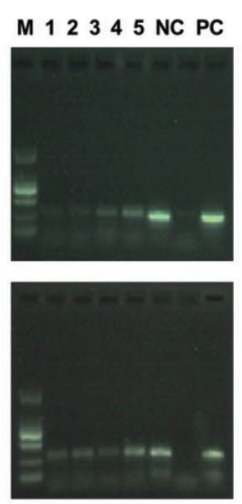

$1 \mathrm{~min}$
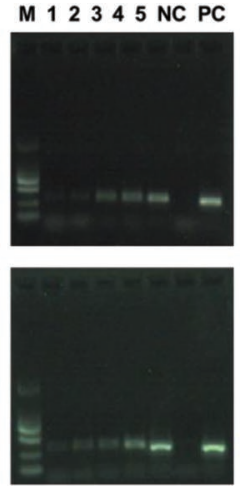

$5 \min$
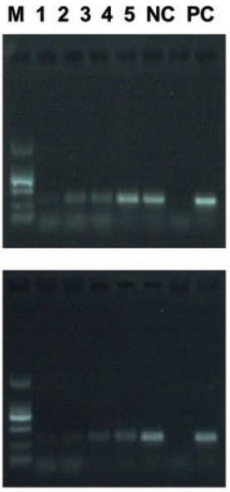

$10 \mathrm{~min}$
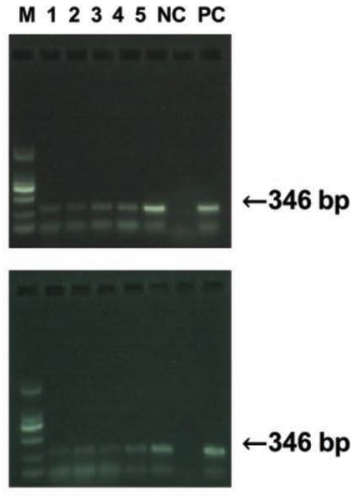

$15 \mathrm{~min}$

Figure 2. Representative gel electrophoresis of 12S PCR products obtained from different heat-treated fresh milk (FM; A) or reconstituted milk (RM; B) in goat milk mixtures. Lanes $1,2,3,4$, and $5=$ mixture of cow and goat milk containing $0.1,0.5,1,10$, and $30 \%$ cow milk composition, respectively; $\mathrm{NC}=$ negative control; $\mathrm{PC}=$ positive control; $\mathrm{M}=$ molecular weight marker $(2,000$-bp DNA ladder). Color version available online. 
milk. Thus, we also assessed the differences in DNA quality between FM and RM following sterilization. The DNA yield, integrity, detection limit, and mtDNA: nDNA ratios were used as parameters in this evaluation.

Determination of double-stranded DNA concentration and purity is important for downstream applications such as PCR and multiplex PCR (BoesenbergSmith et al., 2012). In the present study, the increased DNA yield observed in heat-treated FM and RM probably represents an overestimation because of DNA degradation, given that agarose gel electrophoresis analysis confirmed that the level of DNA degradation was greater in heat-treated than in unheated samples. The partial degradation of double-stranded DNA partially degraded to single-stranded DNA results in an increase in absorbance value of UV light (at $260 \mathrm{~nm}$ ) of DNA solutions, a phenomenon long recognized as

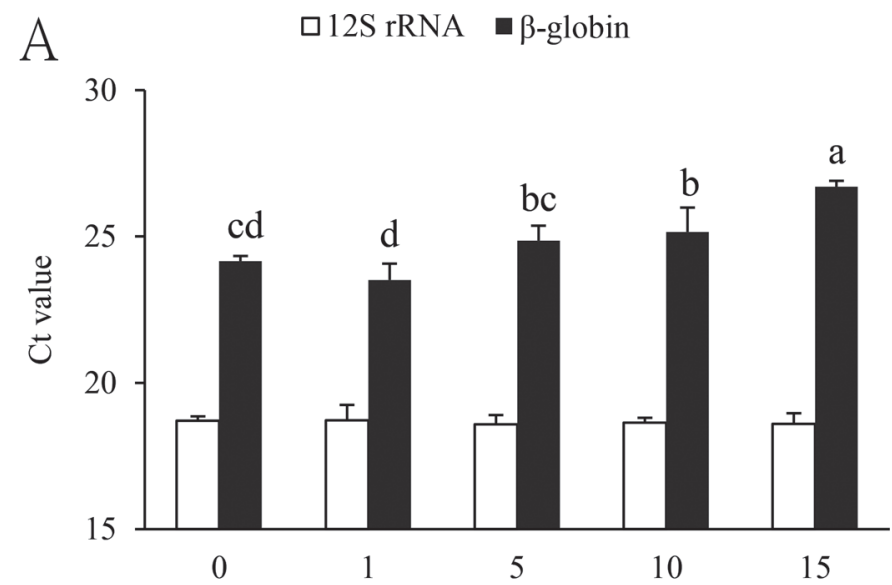

B

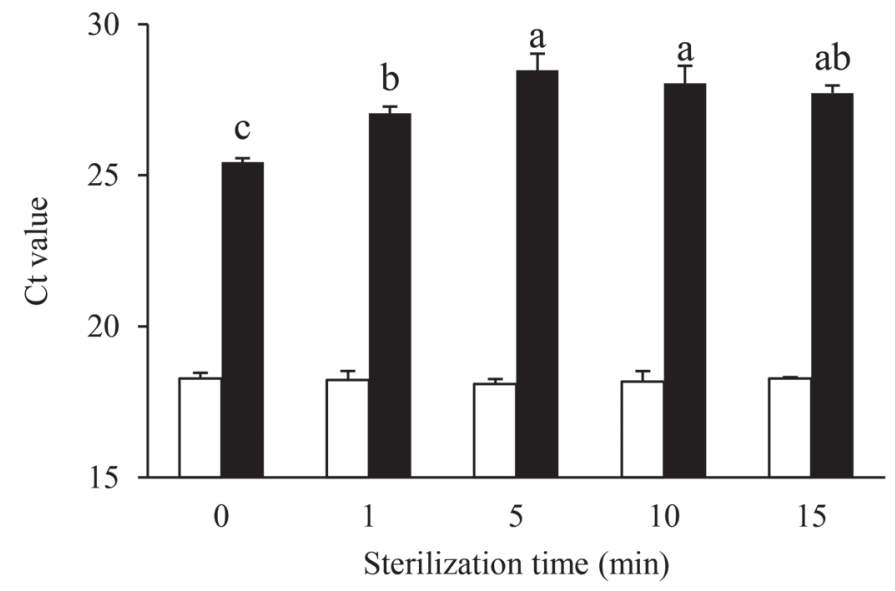

Figure 3. Cycle threshold (Ct) values (mean $\pm \mathrm{SD}$ ) of $12 S$ and $H B B$ in fresh milk (FM; A) and reconstituted milk (RM; B) with different sterilization times. Different letters indicate significant differences among different sterilization times $(P<0.05)$. the hyperchromic effect (Thomas, 1954; Benight et al., 2001).

It has been demonstrated that DNA can be degraded into smaller fragments in processed food products (Novak et al., 2007). In the present study, we found that DNA extracted from heat-treated FM or RM produced weaker bands, indicating that the heating process damaged the integrity of DNA in both FM and RM samples. The DNA bands were no longer evident when FM or RM was heated for up to 15 min above an endpoint core temperature of about $94^{\circ} \mathrm{C}$. The DNA molecules undergo a pronounced contraction when the temperature is raised above a critical value between 88 to $100^{\circ} \mathrm{C}$, leading to degradation and accompanying molecular weight decay (Rice and Doty, 1957).

In the past few years, PCR techniques have been widely applied to species identification in dairy products (López-Calleja et al., 2007; Mafra et al., 2007; Golinelli et al., 2014; Liao et al., 2017a). In the present study, we evaluated the effects of the heating process on the detection limit (lowest milk percentage yielding visible DNA amplification) of FM or RM in cow-goat milk mixtures. We found that the sterilization process used here did not alter the detection limit $(0.1 \%)$ of PCR by amplifying the $12 S$ gene. This detection limit was similar to that in some previous reports. For example, López-Calleja et al. $(2004,2005)$ were able to detect $0.1 \%$ of untreated and heat-treated FM (at $120^{\circ} \mathrm{C}$ for 20 min) in a cow-goat milk mixture. But we also detected $0.1 \%$ of untreated and heat-treated RM (at $121^{\circ} \mathrm{C}$ for 1 , 5,10 , and $15 \mathrm{~min}$ ) in a cow-goat milk mixture.

In recent years, real-time PCR has become a reliable tool for evaluating DNA quantity and quality for downstream applications (Cler et al., 2006; Griffiths et al., 2006; Clements et al., 2008) because Ct values can directly reflect the utility of the extracted template for molecular analysis (Psifidi et al., 2010). According to real-time PCR measurements, the $\mathrm{Ct}$ values of $12 S$ in both FM and RM did not change after sterilization, whereas the $\mathrm{Ct}$ values of $H B B$ in both $\mathrm{FM}$ and $\mathrm{RM}$ showed increasingly poor real-time PCR performance (higher Ct value) as sterilization time extended.

Real-time PCR is commonly used to determine mtDNA:nDNA ratios, a useful indicator for species identification because relative levels of mtDNA differ with source. This technique involves obtaining the ratio of an unknown variable (number of copies of a mitochondrial DNA gene) to a known parameter (number of copies of a nuclear DNA gene) within a genomic DNA sample (Guo et al., 2009). Thus, either mtDNA or nDNA variation can influence the mtDNA:nDNA ratio. In the present study, we found the mtDNA:nDNA ratios from FM and RM increased after sterilization. We suggest that this is a result of nDNA degradation 
in heated samples, resulting in an overestimation of the mtDNA:nDNA ratio, given that sterilization did not significantly influence the amplification of $12 \mathrm{~S}$. Moreover, given that degradation of genomic DNA is a function of increasing sterilization time, the desired amplification region of nDNA was likely disrupted during sterilization. If DNA is extensively degraded, the PCR fragment will be less favorably amplified (Yang and Speller, 2006), which may result in a higher Ct value for nDNA gene. Although real-time PCR may provide accurate mtDNA:nDNA ratios for the genomic DNA samples, these ratios may not accurately reflect the actual mtDNA:nDNA ratios (Guo et al., 2009).

When comparing these parameters between FM and $\mathrm{RM}$, significant differences were observed, including the higher DNA yield and mtDNA:nDNA ratio as well as the weaker bands in RM. It has been reported that heat treatment contributes to greater cell membrane permeability, which may result in more DNA being released from the individual somatic cells (Musto, 2011; Meng et al., 2016). In the present study, RM was reconstituted from milk powder, which was initially produced by removal of water in a heating process. Therefore, the inferior quality of DNA seen in RM may result, in part, from the prior release from somatic cells during the manufacturing of milk powder.

\section{CONCLUSIONS}

In this study, sterilization of milk was shown to affect DNA integrity, yield, and mtDNA:nDNA ratio. Yield of DNA and mtDNA:nDNA ratio in FM and RM varied during sterilization, suggesting that the heating process could confound development of a quantitative method for species identification between untreated and heattreated milk. When heating FM or RM to an endpoint core temperature of about $94^{\circ} \mathrm{C}$, double-stranded DNA could not be detected by direct agarose gel electrophoresis. However, sterilization does not influence the detection limit of PCR; FM or RM composition in goat milk mixtures was detectable by PCR under all treatments, and PCR exhibited a good sensitivity threshold of $0.1 \%$. Furthermore, we found significant differences in DNA yield, integrity, and mtDNA:nDNA ratio between FM and RM during sterilization. These differences may allow for the discrimination of FM and RM.

\section{ACKNOWLEDGMENTS}

This work was supported by the Xi'an city science and technology plan projects of China (Xi'an, China; 2017050NC/NY007-3) and the fundamental research funds for the central universities of China (Beijing, China; GK201502008).

\section{REFERENCES}

Ballari, R. V., and A. Martin. 2013. Assessment of DNA degradation induced by thermal and UV radiation processing: Implications for quantification of genetically modified organisms. Food Chem. 141:2130-2136.

Bauer, T., P. Weller, W. P. Hammes, and C. Hertel. 2003. The effect of processing parameters on DNA degradation in food. Eur. Food Res. Technol. 217:338-343.

Benight, A. S., P. Pančoška, R. Owczarzy, P. M. Vallone, J. Nešetřil, and P. V. Riccelli. 2001. Calculating sequence-dependent melting stability of duplex DNA oligomers and multiplex sequence analysis by graphs. Methods Enzymol. 340:165-192.

Bergerová, E., Z. Godalova, and P. Siekel. 2011. Combined effects of temperature, pressure and low $\mathrm{pH}$ on the amplification of DNA of plant derived foods. Czech J. Food Sci. 29:337-345.

Boesenberg-Smith, K. A., M. M. Pessarakli, and D. M. Wolk. 2012. Assessment of DNA yield and purity: An overlooked detail of PCR troubleshooting. Clin. Microbiol. Newsl. 34:1-6.

Brown, D. E. C. D. Dechow, W. S. Liu, K. J. Harvatine, and T. L. Ott. 2012. Hot topic: association of telomere length with age, herd, and culling in lactating Holsteins. J. Dairy Sci. 95:6384-6387.

Cawthorn, D. M., H. A. Steinman, and L. C. Hoffman. 2013. A high incidence of species substitution and mislabelling detected in meat products sold in South Africa. Food Contr. 32:440-449.

Chen, Y., Y. Wang, Y. Ge, and B. Xu. 2005. Degradation of endogenous and exogenous genes of roundup-ready soybean during food processing. J. Agric. Food Chem. 53:10239-10243.

Clements, D. N., S. Wood, S. D. Carter, and W. E. Ollier. 2008. Assessment of the quality and quantity of genomic DNA recovered from canine blood samples by three different extraction methods. Res. Vet. Sci. 85:74-79.

Cler, L., D. Bu, C. Lewis, and D. Euhus. 2006. A comparison of five methods for extracting DNA from paucicellular clinical samples. Mol. Cell. Probes 20:191-196.

Corredig, M., and D. G. Dalgleish. 1996. Effect of different heat treatments on the strong binding interactions between whey proteins and milk fat globules in whole milk. J. Dairy Res. 63:441-449.

Everstine, K., J. Spink, and S. Kennedy. 2013. Economically motivated adulteration (EMA) of food: Common characteristics of EMA incidents. J. Food Prot. 76:723-735.

Golinelli, L. P., A. C. Carvalho, R. S. Casaes, C. S. C. Lopes, R. Deliza, V. M. F. Paschoalin, and J. T. Silva. 2014. Sensory analysis and species-specific PCR detect bovine milk adulteration of frescal (fresh) goat cheese. J. Dairy Sci. 97:6693-6699.

Griffiths, L. J., M. Anyim, S. R. Doffman, M. Wilks, M. R. Millar, and S. G. Agrawal. 2006. Comparison of DNA extraction methods for Aspergillus fumigatus using real-time PCR. J. Med. Microbiol. 55:1187-1191.

Guo, W., L. Jiang, S. Bhasin, S. M. Khan, and R. H. Swerdlow. 2009. DNA extraction procedures meaningfully influence qPCR-based mtDNA copy number determination. Mitochondrion 9:261-265.

Guoli, Z., Z. Mingguang, Z. Zhijiang, O. Hongsheng, and L. Qiang. 1999. Establishment and application of a polymerase chain reaction for the identification of beef. Meat Sci. 51:233-236.

Laubenthal, L., M. Hoelker, J. Frahm, S. Dänicke, K. Gerlach, K. H. Südekum, H. Sauerwein, and S. Häussler. 2016. Mitochondrial DNA copy number and biogenesis in different tissues of early-and late-lactating dairy cows. J. Dairy Sci. 99:1571-1583.

Liao, J., Y. F. Liu, T. Ku, M. H. Liu, and Y. Huang. 2017a. Qualitative and quantitative identification of adulteration of milk powder using DNA extracted with a novel method. J. Dairy Sci. 100:16571663.

Liao, J., Y. F. Liu, L. Yang, F. P. Li, and A. M. Sheppard. 2017b. Development of a rapid mitochondrial DNA extraction method for species identification in milk and milk products. J. Dairy Sci. 100:7035-7040.

Liu, Y. F., J. L. Gao, Y. F. Yang, T. Ku, and L. S. Zan. 2014. Novel extraction method of genomic DNA suitable for long-fragment amplification from small amounts of milk. J. Dairy Sci. 97:6804-6809. 
López-Calleja, I., I. G. Alonso, V. Fajardo, M. A. Rodríguez, P. E. Hernández, T. García, and R. Martín. 2004. Rapid detection of cows' milk in sheeps' and goats' milk by a species-specific polymerase chain reaction technique. J. Dairy Sci. 87:2839-2845.

López-Calleja, I., I. G. Alonso, V. Fajardo, M. A. Rodríguez, P. E. Hernández, T. García, and R. Martín. 2005. PCR detection of cows' milk in water buffalo milk and mozzarella cheese. Int. Dairy J. 15:1122-1129.

López-Calleja, I. M., I. Gonzalez, V. Fajardo, P. E. Hernandez, T. García, and R. Martín. 2007. Application of an indirect ELISA and a PCR technique for detection of cows' milk in sheep's and goats' milk cheeses. Int. Dairy J. 17:87-93.

Mafra, I., Á. Roxo, I. M. Ferreira, and M. B. P. Oliveira. 2007. A duplex polymerase chain reaction for the quantitative detection of cows' milk in goats' milk cheese. Int. Dairy J. 17:1132-1138.

Martin, G. J. O., R. P. W. Williams, C. Choong, B. Lee, and D. E. Dunstan. 2008. Comparison of rennet gelation using raw and reconstituted skim milk. Int. Dairy J. 18:1077-1080.

Meng, J., Y. Gong, P. Qian, J. Y. Yu, X. J. Zhang, and R. R. Lu. 2016. Combined effects of ultra-high hydrostatic pressure and mild heat on the inactivation of Bacillus subtilis. Lebenson. Wiss. Technol. 68:59-66.

Musto, M. 2011. DNA quality and integrity of nuclear and mitochondrial sequences from beef meat as affected by different cooking methods. Food Technol. Biotechnol. 49:523-528.

Musto, M., D. Faraone, F. Cellini, and E. Musto. 2014. Changes of DNA quality and meat physicochemical properties in bovine supraspinatus muscle during microwave heating. J. Sci. Food Agric. 94:785-791

Nicklas, J. A., E. M. Brooks, T. C. Hunter, R. Single, and R. F. Branda. 2004. Development of a quantitative PCR (TaqMan) assay for relative mitochondrial DNA copy number and the common mitochondrial DNA deletion in the rat. Environ. Mol. Mutagen. 44:313-320.
Novak, J., S. Grausgruber-Gröger, and B. Lukas. 2007. DNA-based authentication of plant extracts. Food Res. Int. 40:388-392.

Psifidi, A., C. I. Dovas, and G. Banos. 2010. A comparison of six methods for genomic DNA extraction suitable for PCR-based genotyping applications using ovine milk samples. Mol. Cell. Probes 24:93-98.

Rice, S. A., and P. Doty. 1957. The thermal denaturation of desoxyribose nucleic acid. J. Am. Chem. Soc. 79:3937-3947.

Sakalar, E., M. F. Abasiyanik, E. Bektik, and A. Tayyrov. 2012. Effect of heat processing on DNA quantification of meat species. J. Food Sci. $77: \mathrm{N} 40-44$.

Song, S., G. Zhou, F. Gao, W. Zhang, L. Qiu, S. Dai, X. Xu, and H. Xiao. 2011. Degradation of transgene DNA in genetically modified herbicide-tolerant rice during food processing. Food Chem. Toxicol. 49:3174-3182.

Spaniolas, S., C. Bazakos, S. Bihmidine, A. Georgousakis, and P. Kalaitzis. 2008. Use of lambda DNA as a marker to assess DNA stability in olive oil during storage. Eur. Food Res. Technol. 227:175-179

Thomas, R. 1954. Research on the denaturation of desoxyribonucleic acids. Biochim. Biophys. Acta 14:231-240.

Wong, E. H. K., and R. H. Hanner. 2008. DNA barcoding detects market substitution in North American seafood. Food Res. Int. 41:828-837.

Yang, D. Y., and C. F. Speller. 2006. Co-amplification of cytochrome $\mathrm{b}$ and D-loop mtDNA fragments for the identification of degraded DNA samples. Mol. Ecol. Notes 6:605-608.

Yoshimura, T., H. Kuribara, T. Kodama, S. Yamata, S. Futo, S. Watanabe, N. Aoki, T. Iizuka, H. Akiyama, T. Maitani, S. Naito, and A. Hino. 2005. Comparative studies of the quantification of genetically modified organisms in foods processed from maize and soy using trial producing. J. Agric. Food Chem. 53:2060-2069. 